wczuć się w ducha ożywiającego wielkiego Pasterza i dają poczucie włączenia w misję Kościoła, który nieustannie apeluje do serca człowieka o przyjęcie orędzia prawdy i miłości. Imponująca jest bibliografia prac Wyszyńskiego wykorzystanych w książce. Obejmuje ona książki, listy i kazania Prymasa. Publikacja nie tylko przybliża duchowe dziedzictwo kardynała Stefana Wyszyńskiego, ale też ukazuje konkretne możliwości zaangażowania się w odnowę Kościoła realizowaną w jego duchu.

ANDRZEJ DERDZIUK OFMCap

Katedra Teologii Moralnej Społecznej KUL

e-mail: aderdziu@kul.pl

DOI: https://doi.org/10.18290/rt.20673-9

\title{
EWANGELICZNA WIZJA GOSPODARKI
}

AdAm ZAdroga, Gospodarka, przedsiębiorczość, praca. Studium z perspektywy katolickiej myśli ekonomiczno-społecznej, Towarzystwo Naukowe KUL, Lublin 2019, ss. 153.

Aktywność zewnętrzna człowieka odsłania jego osobową godność i staje się drogą do rozwijania człowieczeństwa. Osoba, ujawniająca się przez swoje czyny, nie tylko w ten sposób sama pełniej poznaje siebie, odkrywając swoje aspiracje i możliwości, ale też innym uczestnikom życia społecznego ujawnia kim jest. Jednym z istotnych wymiarów ludzkiej aktywności jest praca służąca zdobywaniu pożywienia i zaspokajaniu swoich potrzeb. Przez pracę człowiek rozwija też samego siebie oraz odkrywa swoje miejsce we wspólnocie, nawiązując relacje z innymi ludźmi. Cała aktywność człowieka ma zatem nie tylko swój wymiar techniczny w postaci opanowywania świata zewnętrznego, ale też jest naznaczona wymiarem etycznym, poprzez który człowiek zmienia samego siebie i dostrzega swoją zależność od innych ludzi.

Rozwijająca się dziś ekonomia, zmierzająca do wskazania optymalnych sposobów pomnażania zasobności narodów i szukająca skutecznych dróg zarządzania wytworzonym bogactwem, potrzebuje refleksji etycznej, która wskaże szanse i zagrożenia twórczego zaangażowania człowieka w przetwarzanie świata. Fundamentem refleksji etycznej i jej punktem odniesienia jest prawdziwa koncepcja osoby, która ma swoje najgłębsze zakorzenienie w Objawieniu odwiecznej prawdy i miłości przyniesionym przez Jezusa Chrystusa. Z tym większą radością trzeba powitać nową książkę dr. hab. Adama Zadrogi, która jest owocem jego poszukiwań z zakresu teologii 
moralnej społecznej. Perspektywa teologicznomoralna jest bowiem bardzo użyteczna w całościowym ujmowaniu życia gospodarczo-ekonomicznego, gdyż odwołuje się do racji ostatecznych i wskazuje na dalekosiężne konsekwencje ludzkich wyborów i decyzji. Teologiczne spojrzenie na rzeczywistość udziela też nadziei, która rodzi się z więzi z Bogiem rozwijanej w społeczności Kościoła.

Książka Adama Zadrogi obejmuje trzy rozdziały złożone z kilku artykułów, które Autor publikował wcześniej w nieco zmienionej postaci. Przedmiotem rozważań rozdziału pierwszego jest problematyka relacji gospodarki i moralności. Wychodząc od ukazania antropologicznego fundamentu życia społeczno-ekonomicznego, Autor precyzuje personalistyczne podejście do życia gospodarczego i formułuje postulaty ekonomii społecznej. Swoje wywody opiera na gruncie społecznej nauki Kościoła oraz ilustruje odwołaniem się do teologiczno-społecznej twórczości ks. prof. Janusza Nagórnego.

W rozdziale drugim została podjęta refleksja nad zagadnieniem przedsiębiorczości ujmowanej od strony opisu postawy jako kategorii antropologicznej oraz prezentacji uwarunkowań ekonomicznych tej formy podejścia do kwestii pracy i własności. Konkretnym wyrazem aplikacyjnego charakteru rozważań na temat przedsiębiorczości jest ukazanie postaw chrześcijańskich przedsiębiorców w perspektywie zasad ogólnych i konkretnych świadectw biznesmenów z Polski. Rozdział trzeci dotyczy zagadnienia pracy, wskazując na jej wymiar teologiczny, personalistyczny i moralny. Autor omawia pojęcie pracy w świetle Ewangelii, prawa do pracy oraz jej więzi z powołaniem do życia rodzinnego i otwarciem na życie wieczne.

Książka jest napisana językiem komunikatywnym i jednoznacznym. Niekiedy jest jednak zbyt dużo dosłownych cytatów z dokumentów Kościoła oraz innych autorów. Trzeba też zauważyć, że bibliografia jest niezbyt obszerna, co powoduje, że w niektórych podrozdziałach Autor prawie wyłącznie odwołuje się do dokumentów kościelnych, nie wskazując innej perspektywy ujmowania opisywanych zagadnień. Walorem pracy jest zestawienie istotnych wymiarów ewangelicznego podejścia do bogactwa, przedsiębiorczości i pracy oraz ukazanie sposobu ich ujmowania w świetle katolickiej myśli społecznej. Książka jest ważnym elementem przyczyniającym się do propagowania katolickiej nauki społecznej i może być użyteczną lekturą dla specjalistów z tego zakresu, jak również dla przedsiębiorców szukających odpowiedzi na pytania etyczne pojawiające się w trakcie prowadzenia działalności biznesowej. 